\title{
Governing and managing communal land as a resource in South Africa: A case of selected communal property associations in Vhembe district, Limpopo province
}

\author{
Mokoko P. Sebola \\ Malemela A. Mamabolo \\ University of Limpopo, South Africa
}

\section{Keywords}

Communal Property Associations, Governance, Land reform, Land restitution, Management

\begin{abstract}
This study investigated the governance and management of communal land resources through Communal Property Associations (CPA's) in South Africa using the case of Vhembe district municipality in the Limpopo Province. As at the time of the study Vhembe District had 57 registered $C P A$ 's managing the land on behalf of the beneficiary communities. The study used a qualitative research approach thereby employing a semi structured interview questionnaire to collect data from targeted respondents. A sample of 7 CPA's were selected from a total sample of 57 CPA's in the district in terms of geographical locations of the West (Tshivhula and Leshivha), central (Mulambwane), east (Tshifefe and Manavhela) and the south direction (Mongalo, Machaba). A sample of respondents was between 2 and 3 per CPA which included a group interviews with Chairperson, Deputy Chairperson and Treasurer or Secretary. From the data collected the study concluded that the land managed by the CPA's in Vhembe district faces serious challenges of poor governance, poor support from the government, poor revenue generation by farms or land given back to the community and the high maintenance costs. The study concluded that the adverse governance and management problems of land acquired by the CPA are likely to improve if proper governance principles can be enforced with government effectively monitoring the system for success.
\end{abstract}

\section{Introduction}

In South Africa the CPA's are established under the Communal Property Associations Act no. 28 of 1996. The land held by the CPA's are obtained through the countries land reform, restitution and redistribution programmes. Land in South Africa have been an issue of contestation for centuries with contested claims that South Africa's $87 \%$ of fertile land is owned by the white minority community with only $13 \%$ of infertile land occupied by the majority of African community. A need therefore arose that land need to be distributed equally among South Africans (Centre for Law and Society, 2015:1) through the principles of a legislated land reform programme. Sebola \& Tsheola (2014) have however cautioned that such distribution should take into account the economic role of land used by the white minority so that the process should not devalue the economics of land use. The redistribution of land back to the majority of African communities have been argued to be very slow in implementation with only 6 million hectares given back in 2009 at a backlog of 19 million hectares (Commission for gender Equity, 2009:67; Sebola,2014). While some land has been given back to the African community, some land does not benefit the beneficiary communities as expected by the community and the government itself. In the whole analogy of the systems of managing the land through the CPA model, it becomes clear that governance principles are not clearly adhered to. There is a whole range of governance problems that emanate from the CPA's themselves, the community and the government. This paper therefore raises a question: What is the good governance mechanism that can assist to improve the viability and utilisation of communal land resources (in this case farms) to benefit the local communities? In order to address this question, this paper will keep the relevance of its discussion on the conceptualisation of governance, Economic Activities of the claimed lands and Economic benefit from claimed farms, Research methodology and Results and discussions and conclusion and Recommendations. 


\section{Governance of communal property associations}

Land use, its meaning and management in South Africa stem from many centuries of apartheid and inequity (Camay \& Gordon, n.d:1-5; Department of International Development Southern Africa, 2003:1-7; Clarke, 2009; Urban Landmark, 2013:6) and therefore the problems of land management by the majority of the African people in South Africa is far from being over. The capacity and ability of land to produce massive economic benefits is depended on variety of factors which include quality, adequacy, and proper use (Mataya, Gondo \& Kowero, 2003: 91-93). It is argued that the majority of African communities were not really exposed to issues of land management and use which means that the CPA's which are extremely composed of inexperienced individuals are likely to experience problems when managing farms on behalf of their communities.

Good governance principles are currently overemphasised in any South African organisation whether public or private. Pienaar (2009) noted that ineffective land administration is a potential for economic and political disaster. In the context of South Africa because of the emerging governance principles which are hardly new to local communities there has been reported incidences of conflict between the local communities and the CPA's and to a particular extent with the traditional leadership.

Often it is not clear as to whether CPA's accounts to the government, the community and or traditional leadership. Such lead to complex accountability problems by the CPA and other stakeholders. The multi-accountability complex result in inefficient use of restituted land. Moreover, traditional leaders regard the land acquired through restitution to belong to them on behalf of the community. But to a particular extend the CPA's do not see themselves as being obliged to report to the traditional leadership on CPA activities. Evans \& Gariepy (2015:1) noted a conflict between Bakgatla-Ba- Kgafela in the North West Province in South Africa who took each other to the Constitutional court over who should own the acquired land. In the Eastern Cape, the government had to put a stop on allocating land because Chief Ulana was not happy that his land be put under the administration of the CPA (Center for Law and Society, 2015:2). These abnormalities are indeed a problem which has not been resolved by the government in improving the governance relation between the Chiefs and the CPA's and including the community. As it is argued, the CPA Act of 1996 is not the best of the acts in land administration, however, for now it is the only option and must be observed with its limitations.

In its release of the CPA report 2014/2015 financial year the Department of Rural Development and Land Reform (2013:12) listed the governance challenges of the South African CPA's to include infightings, financial misrepresentations, interdicts, and Intra-CPA litigations. These typical problems when encountered they results in the CPA's themselves not being progressive or cause the Department of Rural Development to focus on dispute resolution than mentoring and support that should be given to the CPA and its beneficiaries. The CPA model was not adopted to devalue the land claimed but adopted to make those land more productive. It is therefore recommendable that if the model of governance does not produce desired results, a need arise that an alternative workable model become a necessity.

\section{Economic activities of the claimed lands}

Land claimed by African communities in South Africa offers various economic opportunities. Sebola \& Tsheola (2014) noted that the South Africa's previously disadvantaged individuals'(blacks) only target to claim the farms that are currently economically active. Although such note is not far from the truth it correlates with the perception held that Africans have been removed from fertile land and therefore are entitled to claim the fertile land (farms) which they have been removed from. Although such claim is justifiable by any means, it only becomes a problem when the African communities (claimants) are not capable of sustaining the economic activities of the farms they inherit from the previous successful(white) farmers.

A number of farms claimed successfully by South African Communal Property Associations possess' variety of economic activities such as Livestock farming, Field crops, Game farming, Citrus and a combination of livestock, field crops and cash crops (Department of Rural Development and Land Reform, 2013:19). It is indeed the wish of the South African government that communal land management through the CPA's should succeed and improve the economic activities of the African communities. It has been noted that the challenges of sustaining the economic activities practiced in the farms by CPA's is not of the making or lack of appropriate management by the CPA, but the poor intervention by the 
government to assists the CPA functions. Various CPA's farms are reported to have collapsed within the first three months of existence by failing to retain the service that was previously given by the previous owners. Many communities have inherited farms that offers services which they hardly have expertise on.

\section{Economic benefit from claimed farms}

On average it is difficult to conclude that there are tangible economic benefits by local communities that are derived from communal farms. A few studies reported negative development on CPA firms such as abandoned land, equipment, and economic decline of restituted farms (Aliber \& Maluleke 2010; Qalam \&Joshua 2012; Sebola \& Tsheola, 2014)). In its preamble the Reconstruction and Development Programme (RDP) states that:

No political democracy can survive and flourish if the mass of our people remains in poverty, without land, without tangible prospects for better life. Attacking poverty and deprivation must therefore be the priority of a democratic South Africa.

In this context it becomes clear that the African National Congress thought that only land available to the majority of the Africans can assists in reducing poverty. While poverty can be reduced by creating communal benefits such as land for agricultural use, such is likely not to be achieved if there is not a clear benefit model that explains how local communities can benefit from restituted farms. The current practice which lack a benefit model have created a situation in which the CPA leadership are themselves viewed as beneficiaries of any economic activity of communal lands. The local communities are often kept aloof from the activities of the communal farms except if they enforce their way by removing the current CPA leadership.

\section{Research methodology}

The study used a qualitative research approach thereby employing a semi structured interview questionnaire to collect data from targeted respondents. A sample of 7 CPA's participated from a total sample of 57 CPA's in the district in terms of geographical locations of the West (Tshivhula and Leshivha), central (Mulambwane), east (Tshifefe and Manavhela) and the south (Chatleka, Mongalo and Machaba). A sample of respondents 3(three) per CPA which included a group interviews with Chairperson, Deputy Chairperson and Treasurer or Secretary. The purpose of selecting three individuals per CPA was meant to avoid biasness of information obtainable from one and two persons and improve the high rate of validity of information obtained.

The study initially targeted $11 \mathrm{CPA}^{\prime}$ s in the Vhembe district, however, only 7 were willing to participate. The other three could not participate as the respondents were of the opinion that there is more criticism of their work by researchers than support from published written materials. Some chairpersons and their committees were of the opinion that they need permission from their constituencies(community) in order to talk about the farm activities. But taking into consideration that this is a qualitative study which probed the perception of the CPA's about the governance, economic activities and economic benefits of the local communities, it only came clear that the opinions of the 7 CPA's can indeed represent the sample of 57 CPA's in the district. This is mainly because the CPA's being studied were in the same district, serviced by the same district and therefore have similar experiences and challenges.

\section{Research findings and discussions}

The research instrument used was a semi-structured interview questionnaire aimed to produce qualitative data through face to face interviews. The researchers intended to investigate the nature of governance of communal farms governed by the CPA's, the type of economic activities practiced in the farm and the extent at which beneficiary communities' benefit from the farms under study. The study was conducted in a period of two weeks and included intensive interviews with the respondents. In total a sample of 24 leadership members of the CPA in Vhembe district were interviewed for purpose of obtaining the information required about governance, economic activities, and community benefit. Data collected is presented hereunder as follows:

\subsection{Governance of Communal Property Associations}

The South African government put more emphasis on principles of good governance characterised by transparent management of communal affairs. In probing governance, the following information 
received attention, i.e. the composition of the CPA membership, availability of the constitution, Election and term of office for CPA leadership, Accountability to the community and understanding of the role of government in the CPA activities.

\subsubsection{The composition of the CPA's membership}

Communal Property Associations are composed of various families that have once stayed together as a community and not necessarily sharing a surname or clan relation. Some CPA's in South Africa have about 500 families which makes the governance incredibly difficult (Sebola, 2018). In this instance responses from Vhembe district shows that family composition in the Vhembe CPA's ranges between 10 and 45. The most CPA's with many family compositions are the Tshivhula and the Leshivha CPA. It may seem the least are the Mongalo and the Machaba CPA where the CPA's predominantly have members of a common surname. It may be argued that the more the CPA has more families there more conflicts arises when families are fighting for authority and recognition to overpower the other families. It is notable from this that the CPA's have been lodged and registered in the names of superior families i.e. Tshivhula, Leshivha, Mulambwane, Manavhela, Mongalo, Chatleka and Machaba while family members attached to these families were used to verify claims lodged by superior families. As such other families attached to these communities are not the equals of those who claims were registered in their names.

\subsubsection{Availability of the Constitution}

The availability of the Constitution is an indication that CPA's activities are conducted in an orderly and professional manner. At the most all interviewees indicated that their CPA's have Constitutions and are operating on constitutional basis. They do however all mentioned that they have not drafted any of the constitutions that they are using to run their CPA's. They indicated that all the constitutions applied were provided for by the government drafted by a consultant employed by the government. An interviewee from the Tshivhula CPA said "The government provides a model constitution, and we adopted it because it covers all aspects which the government expect us to do in the management of the CPA's". It can therefore be deduced from this that the CPA constitution is merely used as a compliant tool which serves the interests of the government than the communities concerned.

\subsubsection{Election and term of office of CPA executives}

Good governance is visible and successful when democratic principles are adhered to through accountability measures. Generally, interviewees on this aspect provide information which differs from individual CPA's to the other. Indeed, all interviewees mentioned that elections are held through a general meeting to elect the new CPA executive. The information provided thus create an opinion that all CPA's existing in Vhembe were put through a democratic system agreed by beneficiary communities. Different terms of office for office bearers is however observed as a practice. Some CPA's indicated that the term of office for their CPA executives is 3 years while others said elections are held after 5 years. Considering the assumption that they are operating on a model constitution drafted by the government, then the term of office should be consistent and similar. Even though such constitutional prescripts seem to exist, arguments do however exist that terms of office other CPA's in Vhembe district show executives long stay characteristics in office. General meetings are normally called by the CPA's for election of new executives, however the results in conflict which compels the existing structures to stay in power.

\subsubsection{Accountability to the community}

The South African CPA's are legally expected to account to both the government (Department of Rural Development and Land Reform) and to the beneficiary communities. The CPA's hold ownership of communal farms on behalf of both the government and the people who elected them to office. The responses from the interviewees about accountability show different viewpoints. The period of accountability to beneficiary communities ranges from a month to three months. On top of that other interviewees argues that meetings can be held regularly for accountability as long as emergency issues for discussion are brought forward. In terms of accountability to government most of the CPA's reported that they account annually to the Department of Land Affairs. An interviewee from the Tshivhula CPA however said that "Indeed the Department of Rural Development and Land Reform requires financial reports on monthly basis". Only one CPA indicated that no report was ever submitted by them to the Department of 
Rural Development and Land Reform. This could be because some CPA leadership within the Vhembe district are of the opinion that sometimes the department itself does not show interests on submitted financial reports from CPA's. It can be deduced from the interviewees that though the government requires such reports, the CPA's are not convinced that an analysis is done by the government to show interest in improving the status quo of farms owned. Reports submitted only fulfils the required compliance procedures.

\subsubsection{Understanding of the role of government in the CPA activities.}

There are at least three government departments involved in restituted land issues in South Africa. Such is the Department of Agriculture, Limpopo Department of Environment and Tourism (LEDET) and Department of Rural Development and Land Reform. These three departments have different role with regard to restituted land. The understanding by the CPA's on how to interact with these departments is significant for survival of CPA's activities in the district. Almost all CPA's in Vhembe knows the role of government through departments of Agriculture, Limpopo Department of Environment and Tourism and Department of Rural Development and Land Reform. The role of those departments is mentioned as in terms of assistance in workshops and training, Financing, and skills transfer, monitoring and dispute resolutions. Only two CPA's in Vhembe were of the opinion that government's role in assisting the CPA is pathetic. The majority felt that the assistance is satisfactory. The role of government is viewed subjectively depending on the type of farm acquired. Most of the respondents whose farming activities are game, and tourism are of the opinion that the Department of Agriculture is not useful to their farms because it only assists those farms that farm on livestock and crop farming. Those in game and tourism farms are to be assisted by the Limpopo Department of Environment and Tourism. The Department of Rural Development and Land Reform however viewed on a positive note by interviewees, some respondents argue that it only buys land for beneficiary communities and later do not provide support. Their role at the end on the day is to hand the farm to the beneficiary communities. It can be deduced that the role of LEDET in farms is slightly not known by the beneficiary communities. The complex role of the Department of Agriculture and the Department of Rural Development and Land Reform in the CPA farms is not well understood.

\subsection{The Nature of economic activities on restituted farms}

Farmland has a variety of economic activities for practicing agricultural activities. Every farm available for use is likely to have certain economic potential which differs from one to the other. The Leadership of the CPA's in Vhembe district were required to provide information on the type of economic activities taking place on their farms. In establishing such, the researchers wanted to know the number of farms acquired, which are the actual economic activities on the farm, which are the most competitive and whether the government support such activities.

\subsubsection{Number of farms acquired by the CPA}

In total the CPA's surveyed in Vhembe district have a total allocation of 40 farms with differing hectares. Mulambwane has the greatest number of about 13 farms successfully acquired through land claim. On average other CPA's have a number of farms ranging from three to a maximum of six. The number of acquisitions is likely to increase as time passes by as claims are still under process. The more the farms are acquired by the beneficiary communities the more various economic activities should be practiced. However, in this case it has shown that the more farms acquired the more managerial complications and conflicts arose among beneficiary members.

\subsubsection{What are actual economic activities on the farm?}

Farms in Vhembe like in all other areas have differing economic potentials. The CPA leadership in the Vhembe district showed that the actual farming activities on the farms are predominantly game farming, lodging, and crop farming. Only two CPA leadership have listed livestock farming and broiler production as economic activities on their farming. Only few farms are said to have sustained the economic activities found in place. 


\subsubsection{Which are the most competitive economic activities on the farm?}

Not all economic activities on the farms have potential to generate revenue for sustaining the land. On average the competitive advantage for economic activities differs on individual farms. The majority of interviewees views game and tourism as twin economic activities for sustaining farm activities within the Vhembe district. Although there are other interviewees that view crop farming and livestock as having the potential, but they also noted that crop farming need expertise which are often not available within the beneficiary communities. Livestock and crop farming are risky for small farmers who are not sufficiently supported by government. To succeed areas such as Vhembe requires that farmers are able to afford livestock feeds and crop fertilizers. Numerous farms successfully claimed in Vhembe district are located within drought areas where rainfall is very scarce thereby threatening both the potential for livestock and crop farming to succeed.

\subsubsection{The government support of economic activities on restituted farms}

The South African government promised to resolve poverty through access to land and promised support in general manner (Sebola, 2018). The support was construed to mean financial support for developmental activities by many South Africans. The Government is however morally obliged to provide support to the communities' economic activities so as to ensure sustainability of farm activities. The majority of the CPA's surveyed in the Vhembe district are of the opinion that the South African government does not sufficiently support the economic activities of their farms. The interviewees, however, acknowledges the provision of the Development grant and the Recapitalisation fund by government as not sufficient to run the activities of the farms. The few that are of the opinion that the governments support is not sufficient argues that not all the CPA's receives the Development grant and Recapitalisation fund on time, and moreover when the money is received a year or two later it is not as promised and has to be used for backlog payment which is not even sufficient. It can be deduced from this that what the beneficiary communities want is to have the government taking full responsibility of the maintenance of their farms. The perception shows that the majority of the beneficiary communities are far from understanding the responsibility to run the farm on their own.

\subsection{The benefits of community from the restituted farms.}

Typically, South African Communal Property Associations faces challenges such as lack of resources, incentives to comply with administrative requirements and limited sanctions for those who fails to comply (Vumela Advisory Fund, 2013:1). This ultimately results in various conflicts among the beneficiary communities that would accuse each other of theft of communal funds by the CPA management. The restituted farms are expected to benefit the beneficiary communities. In trying to establish that on Vhembe district CPA farms the researchers probed the nature of employment opportunities on the farms, number of employees employed in the farms, whether employees are from beneficiary communities, how employees are recruited and whether a farm generate sufficient revenue.

\subsubsection{The nature of employment opportunities on the farms}

The nature of employment activity on the farms at Vhembe differ from one CPA to the other because of differing economic potential in each of the claimed farms. The majority of the interviewees named only one category of employee opportunity that exist in their farms. They mostly talk of the unskilled category though they say only "labourer" employment opportunity exists on their farms. By "labourer" they mean anything that is not categorised as a professional employment. They mentioned opportunities such as general workers, cleaners, looking after the cattle and working in the field. It is only the Tshivhula CPA that indicated that on top of the general labour employee pool they also seasonally employ professional hunters, trackers, Taxidermies, and chefs only and when time provide space for such opportunity. It therefore be deduced that the majority of claimed farms in Vhembe district provides employment opportunity which only offers lower wages.

\subsubsection{Number of employees employed in the restituted farms}

The CPA farms in the Vhembe district differs in size and quantities. There are CPA's that have many farms and those that have lesser farms. The size and quantity may determine the quantity of employees a CPA farm may absorb for employment. According to the interviewees (CPA leadership) in 
the Vhembe District their farms employ between 4 and 20 employees on average. On average many farms in the district employ more than 10 employees. The least employees in the farms are by Chatleka CPA with only 4 employees, while the highest is Manavhela CPA with 20 employees. The employee benefit on this also differs from one farm to the other. From the Mulambwane it is argued that employees there are serving voluntary and they are not any wages from the CPA. In the Tshivhula CPA all 16 employees are paid full wages on monthly basis and therefore they are not volunteers. From this it can be deduced that employees in the CPA's of Vhembe district benefit differently from their employers.

\subsubsection{Are employees in the CPA farms from beneficiary communities?}

One of the sensitivities about communal lands is when the CPA ignores the beneficiaries that have skills to serve their own community. As the Tshivhula CPA indicated about the use of professional hunters which are predominantly white people some may ask as to whether they have explored among their beneficiary as whether there are really no professional hunters among the beneficiary communities. From the interviewees of the CPA in Vhembe district the majority are of the opinion that the beneficiary employees are afforded the opportunity to work in the farms with the previous employees that were found on the farm who are not necessarily from beneficiary community. Of the 12 employees at the Leshivha CPA farm, 4 of them were found on the farm and do not belong to the beneficiary community. The Tshivhula CPA also retained the employees that they found on the farms who are not necessarily from the beneficiary community. Only one CPA (Chatleka) mentioned that they do not employ people from beneficiary communities.

\subsubsection{How are employees recruited to the CPA farms?}

Employee recruitment to serve in CPA farms often cause conflict among beneficiary communities. Despite a need of good governance that the CPA management have to be open and transparent about recruitment process which should ensure equity of benefit to the overall majority, some CPA's may not conform. A general agreement from the majority interviewed is that the vacant positions are made known through word of mouth. The word of mouth is often done through the tribal gathering where interested employees will avail themselves to the CPA for selection. This practice is transparent only to the effect that the majority of the beneficiary community will know about it. The only limitation is that still the CPA executive will make a decision in a manner that might not be transparent. In the case of the Tshivhula CPA because of the scattered beneficiaries the coordinators of the regions will make the availability of the positions known to their constituencies who will in turn inform the coordinator of their interests to the position advertised. Only few interviewees view the employment and recruitment as very flawed especially when ordinary beneficiary have to compete with beneficiaries from the royal families. The royal families often have a major influence on who should be appointed to work in CPA farms.

\subsubsection{Does the farms generate sufficient revenue?}

The sustainability of farm activities broadly depends on the farms capability to generate revenue and sustain the service and employment of the beneficiary communities. Several farms in Limpopo were reported to have failed to sustain themselves after been taken by the CPA's (Sebola \& Tsheola, 2014). It is argued that CPA farms are likely to generate revenue for distribution to families after a long time in which patience is important from beneficiary members. The current beneficiary communities are impatient and by the time the farms are able to generate revenue most would have despaired and leave the farm. Almost information from the entire interviewees except the Tshivhula CPA said that nothing is generated from their CPA farms. They argue that there is no revenue collection of any type at all. The Tshivhula CPA argues that they are able to generate revenue that is sufficient to run all farm activities. The proceeds are not too much but are sufficient to run the farm and pay employees.

\section{Conclusion}

This paper investigated the governance, economic activities of CPA farms and the benefits of the beneficiary communities from the farming activities in the Vhembe district. What clearly came out of this paper is firstly; that the CPA leaderships in the Vhembe district are quite aware of the governance practices required of them by the government of South Africa. It is clear that they adhere to the constitution adopted; they hold meetings as per need and that they account to both their people and the 
government and; that they are of the opinion that the government departments are not doing enough to support their farming activities. Secondly, All CPA's in the district owns more than four farms which unfortunately offers various economic activities which many locals lack skills i.e. game, lodging, and crop farming. The competitive running of these activities by the locals is often problematic. The general perception therefore is that economic activities on the surveyed farms are not successful. Finally, the CPA farms are generally not providing sufficient benefits to beneficiary families in terms of employment or revenue sharing. To the overall interviewees the farms are generating no income and therefore cannot benefit the communities listed as beneficiaries. From this it is therefore recommendable that the government of South Africa through its relevant departments revisits the model of supporting CPA's activities. Financial support and continuous monitoring of the CPA activities will assist to create confidence for CPA executives in performing their functions. The role of the Department of Agriculture in the CPA farm management should be revisited. The fact that the Department of Agriculture only supports crop farming and livestock framing is discriminative against other famers who are engaged in a different agriculture such as game farming.

\section{References}

Camay, P., and Gordon, A.J., 2000. Land restitution and redistribution: providing opportunities for broad-based rural development. Food and Agricultural Organisation of the United Nations: Geneva.

Centre for Law and Society. 2015. Communal Property Associations. Rural Women's Actions Research Programme. University of Cape Town: Cape Town

Commission for Gender Equality. 2009. A Gendered Analysis of Land Reform Policy Implementation Outcome in South Africa. Commission for Gender Equality. South Africa

Department for International Development Southern Africa. 2003. Land issues scoping study: communal Land Tenure areas. McIntosh Xaba \& Associates (Pty) Ltd. Bishopsgate.

Department of Rural Development and Land Reforms. 2013. Draft Land Restitution policy. Government Printers. Pretoria.

Evans, L.C. and Gariepy, R.F., 2015. Measure theory and fine properties of functions. CRC press: London.

Mataya, C., Gondo, P. and Kowero, G., 2004. Evolution of land policies and legislation in Malawi and Zimbabwe: implications for forestry development. Zimbabwe Science News, 36(1): 18-27.

Pienaar, G., 2009. Aspects of land administration in the context of good governance. PER: Potchefstroomse Elektroniese Regsblad, 12(2): 1-54

Sebola, M. P. 2014. Sustaining tourism in South African game farms: the benefits of ownership of restituted land by African communities. Sustainable Tourism VI .187:15-38.

Sebola, M.P. and Tsheola, J.P., 2014. Economics of Agricultural Land Restitution and Redistribution in South Africa: Willing-Seller, Willing-Buyer Business Imperatives versus Socio-political Transformation? J Hum Ecol, 46(2): 113-123.

Sebola, MP 2018. Financing emerging black farmers for agricultural development in South Africa: A wasteful and unworkable model for creating black farmers. The Journal for Transdisciplinary Research in Southern Africa. 14(1):1-7

Urban Landmark. 2013. Land governance in South Africa: implementing the Land Governance Assessment Framework. Global Print: Alexandria. 